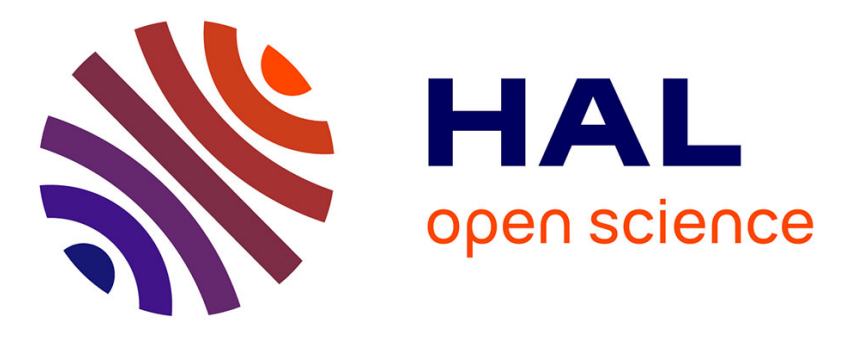

\title{
Dis-locating Public Space: Occupy Rondebosch Common, Cape Town
}

\author{
Myriam Houssay-Holzschuch, Emma Thébault
}

\section{To cite this version:}

Myriam Houssay-Holzschuch, Emma Thébault. Dis-locating Public Space: Occupy Rondebosch Common, Cape Town. Environment and Planning A, 2017, 49 (3), pp.555-571. 10.1177/0308518X15603985 . hal-01198433

\section{HAL Id: hal-01198433 \\ https://hal.science/hal-01198433}

Submitted on 12 Sep 2015

HAL is a multi-disciplinary open access archive for the deposit and dissemination of scientific research documents, whether they are published or not. The documents may come from teaching and research institutions in France or abroad, or from public or private research centers.
L'archive ouverte pluridisciplinaire HAL, est destinée au dépôt et à la diffusion de documents scientifiques de niveau recherche, publiés ou non, émanant des établissements d'enseignement et de recherche français ou étrangers, des laboratoires publics ou privés. 


\section{Dis-locating Public Space: Occupy Rondebosch Common, Cape Town}

Myriam Houssay-Holzschuch

University Grenoble Alpes, UMR 5194 PACTE

Myriam.Houssay@normalesup.org

Emma Thébault ${ }^{1}$

University of Paris I Panthéon-Sorbonne

emma.thebault.paris1@gmail.com

\section{Acknowledgements:}

This research was funded through several projects: ANR PERISUD No. Suds-07-046;

MEDIAGEO No. ANR-09-BLAN-0351-01, DALVAA and the IUF. The authors also wish to thank Olivier Ninot, Martine Berger, Don Mitchell, Lynn Staeheli, Jean-Baptiste Lanne, Kurt Iveson, Darshan Vigneswaran and Ilse Evertse. Special thanks to Zachary Levenson and Elena Etcheverria, who kindly allowed us to use their photo, and to very constructive reviewers.

The final, definitive version of this paper has been published in Environnement \& Planning A, Vol/Issue, Month/Year, DOI $10.1177 / 0308518 \times 15603985$ by SAGE Publications Ltd, All rights reserved. () [M. HoussayHolzschuch, E. Thébaut]

\footnotetext{
${ }^{1}$ Equal authorship.
} 


\title{
Dis-locating Public Space:
}

\section{Occupy Rondebosch Common, Cape Town}

\begin{abstract}
We argue here that public space research might benefit theoretically from the Southern Turn in urban studies. Our first objective is theoretical and methodological: unpack the idea of public space to make it suitable beyond its original location. Détienne's work on Comparing the Incomparable, combined with Staeheli and Mitchell's notion of "regimes of publicity" offer the theoretical tools for such a displacement. We end up thinking about public space as various, context-specific configurations of loosely structured, juridical, political, and social elements that take on new shapes and are prone to partial dislocation when dis-located. We test this model by displacing it to a piece of vacant land - Rondebosch Common in Cape Town. In so doing, we deal with our second objective: offering a detailed empirical analysis of the Occupy Rondebosch Common 2012 events, which relates to broader public space debates in contemporary, liminal, South Africa.
\end{abstract}

"We are the 99\%" - this Occupy Wall Street motto resonates somewhat differently, but no less strongly, when heard from the majority world, also known as the South. Occupy Wall Street was the spark for analyzing majority claims and how they use public space again showing how actual events shape political thought, but also how much our theorizations tend to rest on iconic Western cases and concepts. Public space is such a 
situated and normative notion. However, displacing it to the majority world is in no way straightforward. We therefore argue that public space research might benefit theoretically from the Southern Turn in social sciences, and, more specifically, in urban studies. Public space theories insist on it being crucially important in democratic politics, but tend to neglect postcolonial situations. Here, Partha Chatterjee's (2004, 2011) famous distinction between the civil society of citizens claiming rights on the one hand, and political society, made up of populations to be managed through public policy on the other hand, presents a specific challenge: how political society interacts with public space, and how the political/civil society distinction is played out in and over public space have not yet made it into our theoretical arguments.

It is within this framework that this paper's double objective should be seen. The first objective is theoretical and methodological: unpack the idea of public space to make it suitable beyond its original location and devise ways to make this displacement fruitful instead of an overreach. We test our model of public space by displacing it to a rather untidy piece of vacant land covered by grass and indigenous fynbos - Rondebosch Common in Cape Town. In so doing, we also deal with our second objective: offering a detailed empirical analysis of the Occupy Rondebosch Common 2012 events, which relates to broader public space debates in contemporary South Africa.

\section{Situating Public Space}

Provincializing Public Space 
While powerful voices from the marginalized South have challenged dominant accounts for years (Fanon, 1965), mainstream urban theory and, more generally, social sciences have recently turned towards the epistemological South (see, among many others, Robinson, 2006; Connell, 2007; Roy, 2009; Comaroff and Comaroff, 2011; Edensor and Jayne, 2011; Roy, 2011; Roy and Ong, 2011; Sheppard et al., 2013). The Southern Turn literature challenges existing claims to universalism or exceptionalism; insists on the importance of multi-directional circulations, hybridities, and fluidities; and tries to build a more cosmopolitan scholarship (Robinson, 2003). We believe that such approaches are especially fruitful from a theoretical and an empirical point of view when used midrange: not only for ontological discussions on, for example, what constitutes knowledge, or a person, but also when applied to notions such as privacy (Alizadeh, 2011), or, in our case, public space. In favoring this mid-range work, we, for pragmatic but also heuristic reasons, follow Détienne’s (2008) recommendations regarding 'comparing the incomparable': to select a category that is generic enough, is neither too general nor specific, and neither strong nor weak.

Much of the contemporary understanding of the idea of public space has its roots in the modern, bourgeois West. This does not mean that, as a spatial and political fact, public space is inherently singularly² European (Hallward, 2002), nor that premodern and precolonial societies in what is today the global South did not have spaces for assembly, celebration, or political deliberation (for a Southern African example, see Comaroff, 1985). Furthermore, Western influence has directly (through colonization) or indirectly

\footnotetext{
${ }^{2}$ In this article, the notions of the singular and the specific should be understood within Hallward's (2002) framework, which distinguishes between the non relational singular, which "creates the medium of its own substantial existence or expression," (2) and the specific, which is relational and "allows for the situated articulation of genuinely universalisable principles" (xiii, my emphasis), which are always "produced in a particular situation at a particular time by particular subjects" (183-4, author's emphasis).
} 
exported the concrete forms of European public space to many other parts of the world (Sakai, 2011). Contemporary postcolonial societies have developed "creolized" (Gordon, 2014) and original forms of such spaces (for a recent overview, see Qian, 2014). Nevertheless, actually existing spaces of public expression should be distinguished from "public space" as a normative ideal. The latter carries much ideological and situated luggage that needs unpacking. In typical postcolonial fashion, a Southern take on this much-debated idea of public space (Staeheli and Mitchell, 2007) first highlights its very provincial meaning. The provincial character of public space is multidimensional. Its main theorists (Habermas, 1962) are located in the West; its historico-mythical models stem from European history; its promotion, not to say fetishism, is a staple of many European and North American planners (Toussaint and Zimmerman, 2001; Nemeth, 2009). In this context, public spaces have been seen as places of choice for the expression of citizenship. This very situated ideal of "public space" has thus acquired a multi-layered character, stacking meanings and references to form a very strong normative model in planning practices, political philosophy, and, in the social sciences, as socially virtuous and politically symptomatic. All this does not mean that, as an ideal, "public space" is devoid of substance, but that it should not be unreflexively exported outside its original location to South Africa, which we attempt to do.

\section{Dislocating Public Space}

Further critical inquiry into the idea of public space leads to some conceptual dislocation. Insightful work in the West (Weintraub and Kumar, 1997; Lévy and Lussault, 2003; Mitchell, 2003; Barnett and Low, 2004; Iveson, 2007; Staeheli and 
Mitchell, 2007), in the global South (Navez-Bouchanine, 1991; Capron and Haschar-Noé, 2003), and when comparing across this divide (Sabatier, 2006) has begun to seriously unpack the notion. In our paper, we will follow the proposal formulated in Toulouse (Capron and Haschar-Noé, 2003; Houssay-Holzschuch and Teppo, 2009) by identifying three main streams of meaning: political, legal, and social. The first stream is political and is in keeping with Habermas's work. Public space is therefore characterized as the place where public debate occurs. Its spatial dimension could be just metaphorical. Second, public space takes on a set of meanings of a legal nature. In this case, it covers public property, which typically includes streets, squares, parks, and gardens in the Western model, but could take on a completely different twist elsewhere as in Ethiopia where the State owns the land. In this sense, the spatial dimension of public space is most obvious. The content - that which happens in these physical spaces - is, like its contribution to the political debate, of little importance. Lastly, public space can be defined socially as a set of tangible places where various publics are copresent and even interact. Spaces of anonymity are spaces of unexpected meeting, urbanity understood as density and diversity, and confrontation with difference. Places of contact (Bordreuil, 2000), of rubbing along (Watson, 2006) must be accessible and host "a plurality of uses and perspectives [our translation]" (Joseph, 1998), In such cases, the legal status is ultimately of little importance: a space can be socially public but legally private, as can be cafés, movie theatres, and even public baths as in Seoul. The spatiality of these social public spaces is heavily dependent on the local context: the localization of common spaces varies in space, time, and culture, as does the form they adopt. In specific instances, these three dimensions overlap, often in spectacular ways on specific squares that Bayan and Hatuka (2010) have called "spatial focal points," for example, Taksim in Istanbul, Tiananmen in Beijing (Lee, 2009), and République in Paris. 
We take this dismantling seriously in order to allow the notion to travel and to theorize it in a more cosmopolitan way. That is, in Deleuzo-Guattarian terms, to accept the dislocation that is a consequence of the deterritorialization (or dis-location) of the concept outside its Western place of origin, and to use this looseness to better reterritorialize (or relocate) it in other contexts. We take our cues from two sources: Détienne's (2008) methodological road book for 'comparing the incomparable' and Staeheli and Mitchell's (2007) theoretical proposition of 'regimes of publicity.'

By attempting to compare the "founding, foundation, founder" category across space and time, Détienne and his group narrate how the initial, heuristic, shock of incomparability dislocates the category, leading to a new way of questioning it:

"the comparative approach continually applies two or three questions as a beam in order to scan widely the investigation field whose limits are not fixed yet" (Détienne, 2008)

Then, the logical dismantling operation leads to the identification of (constrained) microconfigurations, "localized plates of quasi causal connections" (Détienne, 2008). In the public space context, the three dimensions (political, juridical, social) listed above can be understood and reformulated as Détienne's beam of questions: where does political debate take place? How is property organized? Where do people of different backgrounds coexist? The three dimensions of public space are thus unhinged from their previous implicit understandings and morphed from norms and certitudes into questions.

Starting with a separate line of questioning dealing with how space is made (and unmade) public, Staeheli and Mitchell (2007) also provide us with a conceptual tool for 
dislocating the idea of public space and for perceiving how the answers to the abovementioned questions should look like: the idea of 'regimes of publicity'. The elements they include in this (namely property relations, social norms and practices of legitimation) are less important for our argument than the idea of the regime, a system of laws, practices, and relations that is specific to a certain place and time. This idea enables us to acknowledge the various situatednesses of publicity. The regime idea also incorporates the idea that "relations of publicity are always simultaneously relatively structured and continually subject to challenge and revision" (Staeheli and Mitchell, 2007). In other words, publicity is not equal to a fixed, unchanging set of (juridical, social, political) conditions whose configuration was organized once and for all in the modern West.

We can push the idea a bit further: beside regimes of publicity, the elements that Staeheli and Mitchell list as structuring specific configurations (to borrow Détienne’s term) can, in turn, also be thought of as regimes. Blomley (2004) has demonstrated this viewpoint most convincingly in terms of property and "regimes of property." Legitimation processes and social norms also appear as various possible sets of laws, practices, and relations: Qian shows that public space production rests on situated and pro-active regimes of social norms, for example, around social cohesiveness and racial harmony in Singapore, or the ideology of national and economic progress in Turkey. We therefore end up thinking about public space as various, context-specific, configurations of juridical, political, and social elements, structured but contested, with the elements themselves context-specific and structured as regimes. This is an almost fractal lens, or a Meccano-like, loosely screwed construction of elements, taking on new shapes as we move it around space and time, and prone to partial dislocation when dis-located. 


\section{Reterritorializing Public Space in Cape Town, South Africa}

The shape of our loosely screwed construction, dis-located then regrounded in contemporary South Africa, and in Cape Town, changes according to several factors.

First, it is powerfully inscribed in a postcolonial context: many contemporary public spaces in the so-called Mother City were designed and maintained for colonial power and control. As such, their very existence belies the lofty diversity ideals of public space romantics: they were "both an expression of power and a subject of political control" (Hou, 2010) - places of exclusion, of repression first and foremost. Such a past cannot be underestimated. They were spaces from which the Khoisan indigenous population had been very early on removed. They were the places where an $18^{\text {th }}$ century society founded on slavery paraded and, later on, where complex and subtle hierarchies of race, class, gender, religion, and origin were played and displayed (Worden et al., 1998). In other words, we apply what Connell (2007) says of globalization theory to the (relocated) idea of public space:

\footnotetext{
'The shared experiences of metropolitan theorists and metropolitan readers do not include much of the sharp end of global social processes. The reason is sociological texts that persistently underplay systemic violence."
}

Second, relocating public space to South Africa embeds it within a second "post" situation, that of postapartheid. Briefly, apartheid, while having multiple dimensions, can also be read through the public space lens as being about shaping its three 
dimensions to mirror and sustain its racist principles (Houssay-Holzschuch and Teppo, 2009; Teppo and Houssay-Holzschuch, 2013). The White regime attempted to exclude the Black majority from the political public space by denying it the most fundamental political and citizen rights. Furthermore, juridical public space was owned by a "Whiteonly" state and an African presence in the city streets was limited by law. Lastly, social public spaces were dismantled by petty apartheid legislation. Conversely, this threedimensional attempt at reshaping public space along apartheid lines also made it a site of resistance.

Third, the situation in contemporary South Africa also shapes what public space is, can, and should be in particular ways. Again very briefly, two divergent forces are at work. On the one side, political democratization has opened up public space (Marais, 2010; Plaut and Holden, 2012), while criminal violence and the highly sensitive perception thereof have generated dialectics of neglect and securitization. On the other side, in an emerging country, globalization and neoliberalism (Narsiah, 2002; McDonald, 2008) generate processes of commodification, touristification, beautification, and privatization of public spaces. While these two processes, colliding in compressed time and space, at first seem at odds, they also produce complex combinations (Hart, 2013). Further, the democratization, which is increasingly seen as electoral only, has sparked new understandings and practices of politics, especially in forming new publics (BénitGbaffou, 2011; Bénit-Gbaffou and Oldfield, 2011; Buire, 2011a; Bénit-Gbaffou, 2012; Selmeczi, 2012). In turn, these have been met with increasing state, and in particular, police violence, "against dissent and the poor" (McMichael, 2013). As McMichael's work demonstrates, while police violence revives fractures from "the colonial and apartheid past," the South African Police Service has used global mega-events, such as the 2010 
soccer World Cup, to fully develop its securitization program and today "defends newer political and business interests established since 1994" (McMichael, 2014). This violence is accompanied by the construction of a discourse criminalizing the poor regarding their "protests (...) for basic rights as the delinquency of a lazy and dangerous underclass" (see also Barchiesi, 2011; McMichael, 2014).

Fourth, Cape Town's particular histories and narratives within South Africa point to the importance of displacement and apartheid removals. Indeed, "[I]f the emblematic figure of African modernity in Johannesburg is the migrant worker, (...)
then in the case of Cape Town, with its history of (limited) racial cohabitation and subsequent
segregation through apartheid, the emblematic urban figure is the victim of forced removal." (Murray et al., 2007)

As Chloé Buire (2011b, 2013) has shown, removals, together with distance, continue to shape urban identities, even for the youth. These removals have also transformed the city and highlight specific center/periphery spatialities: the city center and its core suburbs were declared white areas while racially homogeneous residential neighborhoods ${ }^{3}$ were brutally created on the periphery of the Cape Flats. In between these two spaces, the removals have, together with the colonial past, littered the city with unbuilt or vacant lands: the spaces the forcibly removed left behind, such as the iconic, pericentral neighborhood of District Six; the buffer zones surrounding the townships to better control them; the supersized empty strips surrounding infrastructure that crisscross urban space; golf courses; abandoned military bases; cemeteries; places of nature conservation used for (formerly White) leisure and doubling up as buffer zones... The apartheid city distanced racial groups from one

\footnotetext{
${ }^{3}$ This racial homogeneity is still very much the case in disadvantaged African and Coloured neighborhoods, while a remarkable de-racialization of riches has indeed happened, which the results of the 2011 census show. For detailed maps of the city, see www.adrianfrith.com.
} 
another and these empty public properties embody and enact the role that distance plays in the city. Furthermore, this colonial and apartheid past of removals is still very much present in Cape Town today (Miraftab, 2012), as violent displacement is still an ongoing process throughout the city. Poor, African and Coloured Capetonians have been threatened with evictions in many places such as Joe Slovo (Jordhus-Lier, 2015), Tafelsig, Valhalla Park (Oldfield and Stokke, 2006), Symphony Way (Symphony Way Pavement Dwellers, 2011) or, currently, the Marikana settlement in Philippi.

Fifth, Cape Town has a specific "repertoire of contention" (Ballard, 2005). Contemporary movements draw from recent history to devise their spatial tactics. While townshipbased protests do exist as elsewhere in the country, we want to highlight favorite forms of Capetonian actions: owing to the specifics of the city's demography and economy, they tend to be more multiracial; to have a strong, multi-professional, working-class component; and religious leaders tend to participate. Capetonian protests also favor specific spatialities, which are often linked to roads and, hence, to the persisting coloniality of Cape Town's spatial layout. More specifically, road blockades and marches from the Cape Flats to the city center are two iconic spatial forms of protest. As Ann Harley (2014) has shown, road blockades have increased in recent years, particularly in relation to "service delivery" protests, which she mentions, tends to express the frustration of "surplus humanity," fed up with being not heard or counted. Blockades are very frequent in the far periphery of Cape Town, for example, on Landsowne Road or Baden-Powell Drive. By contrast, marches deploy another spatiality: they bring marginalized people's complaints right to the city center, where the political and economic power lies. 


\section{Rondebosch Common: a place to Occupy}

Khaki to green: the story of a postcolonial open space

One of the seemingly empty interstitial places is Rondebosch Common, a 38 ha open field. Very lightly landscaped, except for a parking spot at the edge and a handful of wooden boards describing the various indigenous species of snakes, toads, and the like found in the fynbos and tall dry grass, it is a beloved open space nested in the Southern Suburbs at the foot of Table Mountain. Looking westwards, towards the mountain, one sees a formerly-proclaimed white, still economically privileged, neighborhood, which the presence of the University of Cape Town renders more cosmopolitan (in race, class, and nationality). Freestanding properties sell for several million rands. Eastwards lies a flatter landscape with expensive houses and gardens often enclosed by high walls. This landscape gradually blends into less well-off neighborhoods forcibly assigned to Coloureds under apartheid.

Rondebosch Common's very existence attests to the notion of public space as a space of control and of privilege: it started as an empty space where the Dutch could camp, followed by the British colonial troops, notably during the two world wars. This latter colonial urban past is still very much present, not only in the memories of older residents, but also in the toponymy of nearby streets, such as Camp Ground. It is also evoked by the historical commentary on some of the boards. The Common's historical 
and environmental value has earned it national heritage status since $1961 .{ }^{4}$ Later on, Rondebosch Common, still vacant, participated in the geography of apartheid by separating, with other pieces of vacant land, the neighborhoods that had been proclaimed white from those that housed 'Non-Europeans,' thus adding a spatial barrier to the many legal ones (Western, 1996; Houssay-Holzschuch, 1999). This material barrier was also filled with racially hierarchized and racist social content: Rondebosch Common was a place of leisure, of sport, of connection to nature, all goods to which White Capetonians had privileged access once the others were forcibly removed 5 .

This race and class barrier still exists: throughout the day, Rondebosch Common welcomes joggers, people walking their dogs, families with young kids on their bikes, and birdwatchers - with an over representation of White and middle-class people. The tall grass, winding paths, and small corners can suddenly reveal an amorous couple, a white yogi, or a businessman using his lunch pause to play with his miniplane. In short, its past as a colonial space of control and privilege still very much marks what happens on Rondebosch Common today.

Time-honored uses have recently gained in importance: the role of Rondebosch Common as a space for conservation has been strengthened. The municipal authorities and local, community-based, organizations support this conservation strongly. Kier Hennessy, of the Spatial Planning \& Urban Design Department of the City of Cape Town, sums up the importance of nature conservation for the municipality:

\footnotetext{
${ }^{4}$ Called a 'National Heritage Site' since 1999.

${ }^{5}$ Coloured and Indian families enjoyed the Common, for example, playing cricket there, before they were forcibly removed, as Kader Asmal, then the Minister for Water Affairs and Forestry, reminisced in the 1990s.
} 
"The big thing in Cape Town is biodiversity. (...) Because the Cape floral kingdom, such a small area of international importance; it's probably, from an urban point of view, one of the hot spots globally, so that has very high significance. So anything with biodiversity significance there's very strong protection of that. But public open space after that, yes it does rate highly, but as I say, we're not ... we don't have the resources to manage it very well." (interview with authors, May 3, 2012)

The fauna and flora of the Common certainly makes it a biodiversity hotspot. It is covered by Cape Flats Sand fynbos, an endemic mix of species, 99\% of which has been destroyed by urbanization, and which the International Union for Conservation of Nature (UICN) considers critically endangered. Nine plant species on the UICN's Red Data list are found on the Common, which also offers a habitat for almost a hundred species of rare birds. This local endemism dovetails perfectly with the wealthier parts of the population's newly found, postapartheid liking for indigenous plants (Ballard and Jones, 2011). The municipality of Cape Town has given Rondebosch Common an important place in its integrated management system for open spaces, the Metropolitan Open Space System (MOSS). This is an effort to brand the city internationally as a sustainable one, one where the exceptional and globally significant environment has a special place. The municipality thus uses its natural heritage to simultaneously build a common local identity and attract international tourists (Natural Wonders! Unlimited Shopping! At the same place!) (Ernstson et al., 2010; Belaidi, 2012; Ernstson, 2013; Ninot and Tallet, 2014). Friends of Rondebosch Common, the non-profit organization to which the municipality has delegated the daily management, is an offshoot of WESSA, the Wildlife and Environmental Society of South Africa. 
At the same time, new uses have taken hold: a Black Rastafari uses the field to gather healing herbs, ashes from vagrant-set fires can be found in the morning, and informal activities, including prostitution, occur on the edges of the Common. The place is therefore becoming more accessible to underprivileged Capetonians, due to its openness and the visibility of what happens, which allow social control. Surveillance of acceptable behaviors, especially of groups ${ }^{6}$, balances its greater inclusiveness in terms of race and class.

Occupy at the southernmost tip of Africa

It is precisely this historical, privileged space of control and nature, in no way a usual space of protest, that became the target of the Cape Town avatar of the global, Cairoinspired, Occupy movement. In Cape Town, however, Occupy was a short-lived event concerning a few hundred people. On January 27, 2012, a 'People’s Summit for Land, Jobs and Housing' was due to take place on the site as part of the action of Occupy Cape Town, a typically heterogeneous and loose get-together of long-time township community activists; protesters from new social movements, such as the Anti-Eviction Campaign; students, middle-class alternative individuals, international aid workers, and the like. ${ }^{7}$ The demographics of the crowd, while predominantly Coloured, showed a very diverse public in terms of race, class, gender, and age. Opposing the postapartheid, neoliberal functioning of Cape Town, they chose to target a (not-so) 'common' piece of

\footnotetext{
${ }^{6}$ One of us witnessed this firsthand: she was having a picnic on the Common with five other people of various ethnicities when nearby residents came to check whether they were not sitting on indigenous plants and suggested that they should sit closer to the parking area "where it is only grass" (Field notes, May 2012).

${ }^{7}$ See the video record of the event: http://vimeo.com/35676658.
} 
land and effectively make it public (Mitchell, 2003), as Jared Sacks, activist of the Occupy movement, explains:

"For this reason locating the summit at Rondebosch Common has special symbolic significance for many of the participants. It represents an immediate assertion of equality within one of the most unequal cities in the world. By taking back the commons, thousands of poor and working-class people, together with many middle-class allies, are saying that they no longer want to live in a city which remains segregated under the shadow of Hoerikwaggo (more recently known as Table Mountain), where some live in huge mansions while others live in $10 \times 10$ meter shacks, where some are paid millions and others spend their whole lives underemployed."8

When we interviewed him, he elaborated on the reasons for choosing Rondebosch Common as a target, for both what it represents and how the privileged would perceive its occupation:

"I think one of the brilliant aspects of the take back Rondebosch Commons action was that it spoke to the biggest fear among whites ... white Capetonians especially, and especially wealthy Capetonians, is that their white areas would be invaded by poor black people and that scared the people in Rondebosch and Mowbray area, like nothing since the end of apartheid. They were terrified. There was postings all over the internet by different people about how this was going to happen and it was going to destroy Rondebosch (...) and there was this paranoia was like amazing, you know (...) I mean the Rondebosch Common kind of represents segregation, it represents whiteness, it represents the racism of Cape Town, it represents all these inequalities in Cape Town, I think." (interview with authors, May 12, 2012)

Other participants, such as Mike Hoffmeester, Chairman of the Bishop Lavis [a poor Coloured township] Outreach Forum, were even more straightforward:

“Those people can take their dogs and stroll there and, you know, jog there. You can do that, you are free to do that, but it is not fair to the poorest of the poor. Why must you take your dogs there and we are 40 people on one plot?" (April 19, 2012)

The summit intended to discuss alternative and socially more just development

${ }^{8}$ Jared Sacks, http://bolekaja.wordpress.com/2012/01/26/taking-back-the-commons-in-cape-town/. 
perspectives for the city of Cape Town. Through banners, T-shirts, discourses, and some of the activists' personal history, its demands drew on the specifically Capetonian tradition of protest that we discussed earlier. On that day, the discourses reworked the familiar idiom of the Struggle into contemporary demands, pointing to not-as-yetfulfilled basic needs. While very much in sync with the global Occupy movement, Occupy Rondebosch Common (ORC) was deeply and explicitly reterritorialized. Not only were the public and idiom very local in nature, but the chosen location also did not conform to global Occupy practices; it had symbolic relevance locally and the demands were specific. The global Occupy movement's financial focus had been explicitly rejected in previous discussions ${ }^{9}$ as not speaking to local priorities, where housing is a more pressing issue for the many people who have neither a house, nor a bank account.

In line with contemporary local state practices (Pithouse, 2008; McMichael, 2014), the municipality declared the event illegal. The authorities and apartheid-era armored vehicles stopped different marches, which were planned to converge on the Common on their way, while Casspirs met the remaining protesters on the site (Figure 1). In what appears to be a clear overreach of the Gatherings Act, forty people were arrested. ${ }^{10}$ The mayor Patricia de Lille was compared to apartheid hardliner P.W. Botha, or derided by columnists quipping that "Mario Wanza's [one of the organizers] occupiers should have worn jogging shorts" as "anybody may occupy Rondebosch Common (...) at any time. I often occupy it myself, taking our dogs for a walk."11

\footnotetext{
${ }^{9}$ Jared Sacks, interview, May 12, 2012.

10 Ndenze, B. 2012. Analyst likens De Lille to PW Botha. Cape Times, February 1. See also constitutional expert Pierre de Vos's analysis (http://constitutionallyspeaking.co.za/siessa-patricia/, posted on January 30, 2012, accessed on December 11, 2013).

11 Scott, J. 2012. Mario Wanza's occupiers should have worn jogging shorts. Cape Times, February 7.
} 

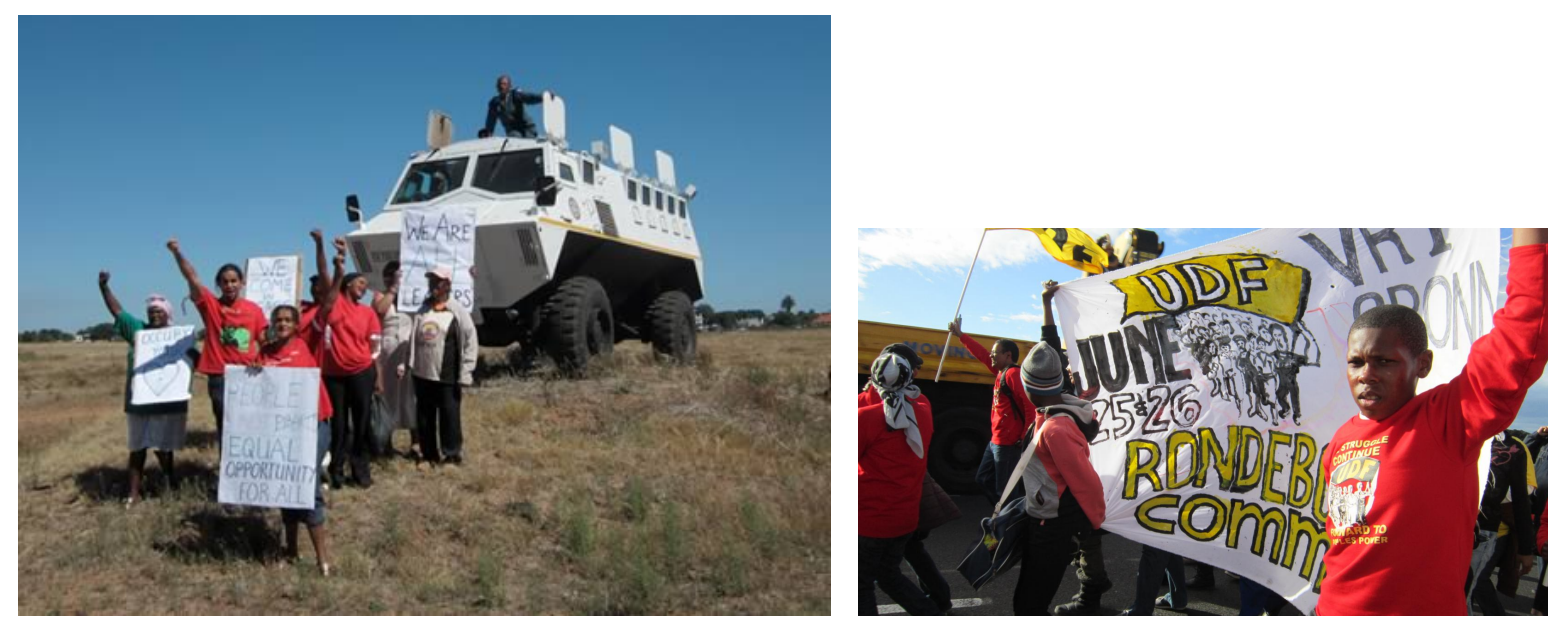

Figure 1: Occupy Rondebosch Common: the January 2012 repression and the June 2012 'Freedom Charter March' with UDF banners and T-shirts.

Source: Zachary Levenson, Elena Echevarria (used with permission); Authors, June $25,2012$.

A few days later, the reclaiming of Rondebosch Common by those who had been excluded from it took a deeper historical meaning when indigenous Khoisan leaders gathered at the site on February 5. This incident put what happens on the site in an even starker postcolonial light, as these leaders' ancestors had borne the brunt of the Cape's colonization - almost to the point of extinction during the $17^{\text {th }}$ and $18^{\text {th }}$ centuries. They had suffered war, smallpox, systematic and organized manhunts, and enslavement. With the support of Occupy Cape Town, they convened a cleansing ceremony ${ }^{12}$ and renamed the site Tsui//Goab, which, in the indigenous language, means the one who spreads green on this earth. This renaming is materialized by a still visible wooden board. Such indigenous claims and ritual practices are a recent, postapartheid addition to the Capetonian vocabulary of protest.

\footnotetext{
12 It can be seen on Youtube, http://www.youtube.com/watch?v=mdTkpSEk818.
} 
Discourses on the legitimacy of the Occupy actions and the repression flooded the local and national press, as well as the internet. The interplay between the global Occupy movement on the one hand, and the local, reterritorialized challenges of the January and February events on the other hand, clearly framed the Occupy Cape Town and the Khoisan actions. The local environmentalists expressed fears that the Occupiers would damage the fynbos - the impact of the Casspir's heavy tires going unmentioned. Jared Sacks points out the ironies of such a discourse, which is aligned with some South African conservationists "conservatively positioning themselves as stewards of the environment in contrast to what they believe to be the environmentally damaging poor black population" (Ballard and Jones, 2011):

“[I]t's hypocritical of them to make an issue over [the environment] when they're not making issues of how they're living their lives and everything else. I think they're using the environmental concern as an excuse for most of them, as an excuse to prevent people from being in the area. I do think the environmental concern is something that needs to be addressed, however, there are other spaces ... that space is home to certain important fynbos, right, but there are other spaces in Cape Town that are also home to that fynbos. And it's not such a vital issue ... that people should still live in shacks for. Because ... the real issue that destroying our environment is other issues. Fynbos is important, but we have a whole mountain full of it, you know. There's the Kenilworth Racecourse that has fynbos on it that has the same fynbos that's on the Commons, it's also very important, but they still built a racecourse around it, you know." (Interview with authors, May 12, 2012)

A Cape Times op-ed justified the heavy-handed repression that the mayor ordered with the well-rehearsed, following arguments (Oldfield and Stokke, 2006; Selmeczi, 2012; McMichael, 2014)13: Patricia de Lille herself started by de-legitimizing the claims of the Occupy people, asking "where is their common sense?" She accused the (multiracial) protesters of using the race card and belittling municipal efforts to build an inclusive

\footnotetext{
13 de Lille, P. 2012. 'Occupiers' see only what suits them. Cape Times, February 7.
} 
city. In other words, protesters were "labeled by the political elites as 'scum', 'rabble', 'racaille', the ochlos who do not belong to the demos; they are the Rancièrian 'part of nopart'” (Swyngedouw, 2014), the uncivil subalterns making up political society and in need of being firmly governed. She also settled personal political accounts with Mario Wanza and the ANC opposition leader Tony Ehrenreich (who, to the best of our knowledge, did not participate in the event itself, but in a follow-up one that tradeunions organized a few days later).

ORC was the most visible and advertised action of Occupy Cape Town, which later mainly consisted of liaising with and supporting other social movements like the AntiEviction Campaign and Abahlali baseMjondolo. But the site itself hosted another mass action on June 25, 2012 (Figure 1). Mario Wanza mobilized Cape Flats communities under the banner of the Communities for Social Change organization, of which his support base, Proudly Manenberg, is a key component. A couple of hundred people marched from the Cape Flats to Rondebosch Common with the municipality's authorization, aiming (unsuccessfully) at relaunching the UDF14 mass movement as an alternative to the ANC and the DA (respectively in power at the national and provincial and municipal levels) and demanded that the Freedom Charter be applied. ${ }^{15}$ ANC heavyweights dismissed this action as Wanza's personal political strategy ${ }^{16}$. This interpretation was fueled by his previous and later sidings with various causes that could further his political career, but his action nevertheless resonated strongly with

\footnotetext{
14 The United Democratic Front, a mass organization created in 1983 that acted as the main organization fighting apartheid from inside South Africa while the ANC was banned.

15 The Freedom Charter is a 1955 document outlining the principles of a democratic South Africa and signed by various anti-apartheid parties, including the ANC. Its idealistic content is now often used to show how much the ANC government has diverged from the principles and aims of the anti-apartheid struggle.

16 Nicholson Z., "Old guard present a united front as 'opportunists' attempt to relaunch UDF”, Cape Times E-dition, 20 Aug 2012
} 
other social movements' similar demands that the promise of democracy should be fulfilled to make the - in their view - electoral only democracy economically and socially efficient (see among many others Selmeczi 2012; Ballard, Habib, and Valodia 2006).

Rondebosch Common thus appears to be a public space that had long been public in name only. The postapartheid democratization has allowed this geography to be contested, and has attempted to make Rondebosch Common truly common and effectively public. This was first done by means of "quiet encroachments" (Bayat, 2000) and new everyday practices, thus making the space accessible to a wider, more inclusive public in racial and social terms. Subsequently, this was done through highly visible attempts to use it as a space of public formation, expression, and political claims. Although ultimately unsuccessful, these attempts tried to combine two spatial strategies of protest, updated to be more transgressive ${ }^{17}$ :

- The time-honored marching from the peripheries to the center. ORC shifted its target by not aiming for the CBD and overt places of power (e.g. the now democratically elected Parliament). Instead, it aimed for another core area, where structural inequalities still manifest themselves through housing and land ownership.

- A will to occupy, displaced from its usual township location (Harley, 2014) to an inbetween buffer space in a formerly white, still exclusive and secluded, suburb, chosen for its symbolic location (Hammond, 2013) and name.

\section{Theoretical conclusions}

\footnotetext{
17 Our thanks to the reviewer who suggested this.
} 
This article set out with a two-pronged objective: suggesting a theoretical and methodological model for using the idea of public space out of its Western context of origin and testing this model through the case study of the Rondebosch Common events. Our conclusions will therefore start by assessing what happened on Rondebosch Common before returning to the model.

\section{Public making on the Common}

What kind of public space does all this make? If we go back to the Détienne-inspired beam of questions - How is property organized? Where do people of different backgrounds coexist? Where does political debate take place? - to be directed at dislocated public space, the Rondebosch Common case comprises several aspects, all pointing to a possible Rancièran reading of the events:

- Because Rondebosch Common is public property, it can be more easily used for legal protest in terms of the Gathering Act. At the same time, how property is organized is precisely what the gathering contested: demanding land and houses for the poor directly challenges the existing, inherited, and racially-skewed property regime. Further, this regime has instrumentalized environmental protection and historical heritage in order to freeze the Common land and prevent meaningful changes. At the same time, ORC highlighted the distinction between property and ownership (Bresnihan and Byrne, 2014): while the Common is public property and managed as such, it should belong to the People. In other words, would-be occupiers expressed a "refusal to observe the "place" allocated to people and things (or, at least, to particular people and things)" (Robson, 2005; quoted in Swyngedouw, 2014) in a particular police order. This disruption is precisely what Rancière (1999) describes as the properly political. 
- ORC also delineated a new public through the copresence of people from different backgrounds on the site. In a highly divided and unequal postcolonial city (Samara et al., 2013), the point of the gathering was not to resolve ethnic or class differences, but rather to play them out, to display them using the traditional theatrical quality of public space in a democracy (Joseph, 1995) relayed in the virtual public sphere of blogs, Facebook groups, and on-line videos. In so doing, ORC claimed to manifest, even establish, the actual Cape Town public in all its heterogeneity - a public for which a space still needs to be carved out. Crucially, the public on the common is not a pre-existing one, for example, class- or race-based, but is engaged in political subjectivation through their very protest. "These subjects do not have the consistency of coherent social groups united by a common property or a common birth, etc. They exist entirely within the act, and their actions are manifestations of a dissensus" (Rancière, 2000; on heterogeneous publics, see also Ross, 2002).

- As a public space, the political dimension of Rondebosch Common was implicit until the action of Occupy, whose actions spelled it out in no uncertain terms in the sense that the Common was used for staging a deliberate and textbook "act of citizenship" (Isin and Nielsen, 2008). Occupy Rondebosch Common meets the condition for a properly political event in Rancièran terms. First, it disrupted the existing spatial order, and as Rancière himself says

\footnotetext{
"In the end, everything in politics turns on the distribution of spaces. What are these places? How do they function? Why are they there? Who can occupy them? For me, political action always acts upon the social as the litigious distribution of places and roles. It is always a matter of knowing who is qualified to say what a particular place is and what is done in it. (Rancière, 2003; quoted in Davidson and Iveson, 2014)
} 
Second, it actualized a new public and "[p]olitics (...) do not only emerge from the margins (...), as if a structurally determined and excluded 'part with no part' gains conscious and enunciates a demand that changes the society around it. Rather its constituent elements are the stakes of battle themselves" (Davidson and Iveson, 2014). John Adams, president of the Ruyterwacht Tenants Committee, and one of the organizing members of Occupy Cape Town, summarized this viewpoint when he affirmed: "There is no government, we are the government". ${ }^{18}$

ORC's action took place in a spatial, but also temporal, niche: the colonial and apartheid pasts still inform spatial forms and social relations, while democracy is seen as a promise suspended, in limbo, electoral but not effective. It is this entanglement of temporalities (Mbembe, 2001; Gervais-Lambony, 2003) that creates a specific regime of publicity, which is transitional and transactional. Although all regimes of publicity contain elements of transition - they are historically constructed - and transactions, they are always contested and fought for (Mitchell, 2003). As such, the South African regime of publicity is not ontologically different, reminding us that theorizing from the South should not lead to essentialism. Nevertheless, the specific situation in contemporary South Africa makes for a regime of publicity that is especially transitional and transactional.

Ultimately though, ORC can be understood as showcasing a liminal regime of publicity in spatial and temporal terms. The Common is a space in-between, a spatial threshold, as are the times in contemporary South Africa. Thomassen (2014) reminds us that liminality is "about how larger groups or entire societies undergo change and

\footnotetext{
${ }^{18} \mathrm{http}: / /$ vimeo.com/35676658.
} 
transition". More specifically, the liminality of ORC's regime of publicity is what Szakolczai (1999) calls frozen liminality. Building on van Gennep's rites of passage and their three steps (separation, liminality proper, and re-aggregation), Szakolczai suggests that "when any of the phases in this sequence becomes frozen," then "temporary liminal conditions [become] permanent." This notion strongly resonates with the "suspended revolution" (Habib, 2013) which South Africa scholars discuss. Activists use the postliberation national narrative, which the ruling ANC promotes, to take politicians at their word, to make counterclaims regarding delivery and accountability or, conversely, betrayal (Hart, 2013). In short, these activists demand that the country's very progressive constitution should be applied. Still, it is precisely these demands that are not met - or only by state violence - leaving democratization inconclusive and frozen before it is actualized.

\section{Public space Meccano at work}

Lastly, how does Occupy Rondebosch Common speak back to our general ideas about public space? Decentering Occupy to the southern tip of Africa seems to unhinge, rather than obliterate, our ideas of public space. A specific, situated, and relational regime of publicity is (re)configured through the unraveling of the particular set of conditions presiding over its reterritorialization. The interconnected three dimensions of public space are set in a configuration that points towards the political significance of the event. Our theorization-cum-method Meccano is therefore operational here. It has certainly helped us avoid the imperialist exportation of opaque Western notions and the exoticizing singularities (in Hallward's sense) of a "Southern case" of popular politics. It also opens up a debate with Chatterjee's theorizing of civil vs. political society. As much as his reminder that " $[\mathrm{m}]$ ost of the inhabitants of India are only tenuously, and even 
then ambiguously and contextually, rights-bearing citizens in the sense imagined by the constitution" (2004) resonates with the South African case of suspended democracy (see also Bénit-Gbaffou and Oldfield, 2011), his rigid and binary opposition contradicts ORC's practices and political significance. The spatialities of the ORC's protest, which drew people from the peripheries to the Common, its demands for the actualization of democratic rights (including for land and houses), as well as the way it created a heterogeneous (i.e., nonbinary in terms of race or class, or civil/political) public, all cross existing, social, and urban, divisions. This reconfiguration is partly the result of the distinct political work that the language of the $\mathrm{C} /$ common/s accomplished as a rhetorical device. Jared Sacks was very explicit about this:

\footnotetext{
"If the commons is for all in name only, then it does not exist. Thus, the "Take Back the Commons' movement aims to liberate public spaces such as Rondebosch Common. It must be for all to use and enjoy, not only for a privileged few to hoard."19
}

\section{References}

Alizadeh H, 2011, "The Concept of Privacy and Space in the Kurdish Cities' built form", in A World of Cities: Urban Theory Beyond the West Eds T Edensor, M Jayne (Routledge, London) pp 137-156

Ballard R, 2005, "Social Movements in Post Apartheid South Africa: An Introduction", in Democratising Development: The Politics of Socio-Economic Rights in South Africa Eds P Jones, K Stokke (Martinus Nijhoff, Leiden \& Boston) pp 77-100

Ballard R, Jones G A, 2011, "Natural Neighbors: Indigenous Landscapes and Eco-Estates in Durban, South Africa" Annals of the Association of American Geographers 101 131-148 Barchiesi F, 2011 Precarious Liberation: Workers, the State, and Contested Social Citizenship in Postapartheid South Africa (State University of New York Press in cooperation with the University of KwaZulu-Natal (UKZN) Press, Albany) Barnett C, Low M, 2004 Spaces of democracy : geographical perspectives on citizenship, participation and representation (SAGE, London ; Thousand Oaks, Calif.) Bayat A, 2000, "From `Dangerous Classes' to 'Quiet Rebels': Politics of the Urban Subaltern in the Global South" International Sociology 15 533-557

\footnotetext{
${ }^{19}$ http://bolekaja.wordpress.com/2012/01/26/taking-back-the-commons-in-cape-town/.
} 
Baykan A, Hatuka T, 2010, "Politics and culture in the making of public space: Taksim Square, 1 May 1977, Istanbul" Planning Perspectives 2549 - 68

Belaidi N, 2012, "Le Patrimoine mondial pour créer une identité commune dans l'Afrique du Sud post-apartheid. Exemple de la ville du Cap", in Patrimoine mondial et tourisme Eds L Bourdeau, M Gravari-Barbas, M Robinson (Presses de l'Université Laval, Québec) pp 269-284

Bénit-Gbaffou C, 2011, "'Up Close and Personal' - How does Local Democracy Help the Poor Access the State? Stories of Accountability and Clientelism in Johannesburg" Journal of Asian and African Studies 46 453-464

Bénit-Gbaffou C, 2012, "Party politics, civil society and local democracy: Reflections from Johannesburg" Geoforum 43 178-189

Bénit-Gbaffou C, Oldfield S, 2011, "Accessing the State: Everyday Practices and Politics in Cities of the South" Journal of Asian and African Studies 46 445-452

Blomley N K, 2004 Unsettling the city: urban land and the politics of property (Routledge, New York)

Bordreuil J-S, 2000, "La ville desserrée", in La ville et l'urbain - l'état des savoir Eds T Paquot, M Lussault, S Body-Gendrot (La Découverte, Paris) pp 169-182

Bresnihan P, Byrne M, 2014, "Escape into the City: Everyday Practices of Commoning and the Production of Urban Space in Dublin" Antipode n/a-n/a

Buire C, 2011a, "'Bringing Government Closer to the People'? The Daily Experience of Sub-councils in Cape Town" Journal of Asian and African Studies 46 465-478

Buire $\mathrm{C}, 2011 \mathrm{~b}$ À travers pratiques citadines et tactiques citoyennes, la production du droit à la ville au Cap (Afrique du Sud) Ph.D. in Geography, Département de géography, Université de Paris Ouest Nanterre La Défense, Nanterre

Buire C, 2013, "Les "lignes de fuite" des identités citadines après l'apartheid" Justice spatiale / Spatial Justice

Capron G, Haschar-Noé N, 2003, "L'Espace public en question : usages, ambiances et participation citoyenne", in Études et travaux de l'école doctorale TESC (Université de Toulouse Le Mirail, Toulouse)

Chatterjee P, 2004 The politics of the governed : reflections on popular politics in most of the world (Columbia University Press, New York)

Chatterjee P, 2011 Lineages of political society : studies in postcolonial democracy

(Columbia University Press, New York)

Comaroff J, 1985 Body of Power, Spirit of Resistance: The Culture and History of the South African People (University of Chicago, Chicago)

Comaroff J, Comaroff J L, 2011 Theory from the south, or, How Euro-America is evolving toward Africa (Paradigm Publishers, Boulder, CO)

Connell R, 2007 Southern Theory. The Gobal Dynamics of Knowledge in Social Science (Polity, Cambridge)

Davidson M, Iveson K, 2014, "Occupations, mediations, subjectifications: fabricating politics" Space and Polity 18 137-152

Détienne M, 2008 Comparing the incomparable (Stanford University Press, Stanford, Calif.)

Edensor T, Jayne M, 2011 A World of Cities: Urban Theory Beyond the West (Routledge, London)

Ernstson H, 2013, "Re-Translating Nature in Post- Apartheid Cape Town: The Material Semiotics of People and Plants at Bottom Road", in Actor-Network Theory for Development Working Paper Series (Centre for Development Informatics, Institute for Development Policy and Management, SED, University of Manchester, Manchester) 
Ernstson H, van der Leeuw S E, Redman C L, Meffert D J, Davis G, Alfsen C, Elmqvist T, 2010, "Urban Transitions: On Urban Resilience and Human-Dominated Ecosystems" AMBIO

Fanon F, 1965 The wretched of the earth (Grove Press, New York,)

Gervais-Lambony P, 2003, "Afrique du Sud, les temps du changement" Hérodote 81-98

Gordon J A, 2014 Creolizing Political Theory. Reading Rousseau through Fanon (Fordham

University Press, Bronx)

Habermas J, 1962 Strukturwandel der Öffentlichkeit (Luchterhand, Berlin)

Habib A, 2013 South Africa's Suspended Revolution. Hopes and Prospects (Wits University

Press, Johannesburg)

Hallward P, 2002 Absolutely Postcoonial: Writing between the singular and the specific

(Manchester University Press, Manchester)

Hammond J L, 2013, "The significance of space in Occupy Wall Street" Interface: $a$

journal for and about social movements 5 499-524

Harley A, 2014, "The pedagogy of road blockades" Interface: a journal for and about social movements 6 266-296

Hart G P, 2013 Rethinking the South African Crisis : Nationalism, Populism, Hegemony

(University of Kwazulu-Natal Press, Durban)

Hou J, 2010 Insurgent public space : guerrilla urbanism and the remaking of

contemporary cities (Routledge, New York)

Houssay-Holzschuch M, 1999 Le Cap, ville sud-africaine : Ville blanche, vies noires

(L'Harmattan, Paris)

Houssay-Holzschuch M, Teppo A, 2009, "A mall for all? Race and public space in postapartheid Cape Town" Cultural Geographies 16 351-379

Isin E F, Nielsen G M, 2008 Acts of citizenship (Zed Books, London)

Iveson K, 2007 Publics and the city (Blackwell Pub., Malden, MA ; Oxford)

Jordhus-Lier D, 2015, "Community resistance to megaprojects: The case of the N2 Gateway project in Joe Slovo informal settlement, Cape Town" Habitat International 169-176

Joseph I, 1995 Prendre place. Espace public et culture dramatique (éditions Recherches, Paris)

Joseph I, 1998 La ville sans qualités (Éditions de l'Aube, La Tour d'Aigues)

Lee N K, 2009, "How is a political public space made? - The birth of Tiananmen Square and the May Fourth Movement" Political Geography 28 32-43

Lévy J, Lussault M, 2003 Dictionnaire de la géographie et de l'espace des sociétés (Belin, Paris)

Marais H, 2010 South Africa pushed to the limit : the political economy of change (UCT

Press, Claremont, Cape Town)

Mbembe A, 2001 On the postcolony (University of California Press, Berkeley)

McDonald D A, 2008 World city syndrome : neoliberalism and inequality in Cape Town

(Routledge, New York)

McMichael C, 2013, "'Clearly Blown Away by the End of The Morning's Drama':

Spectacle, Pacification and the 2010 World Cup, South Africa" Socialist Studies / Études

socialistes 9 111-129

McMichael C, 2014, "Police wars and state repression in South Africa" Journal of Asian and African Studies

Miraftab F, 2012, "Colonial Present: Legacies of the Past in Contemporary Urban

Practices in Cape Town, South Africa" Journal of Planning History 11 283-307 
Mitchell D, 2003 The Right to the City : Social Justice and the Fight for Public Space (Guilford Press, New York)

Murray N, Shepherd N, Hall M, 2007 Desire lines: space, memory and identity in the postapartheid city (Routledge, New York)

Narsiah S, 2002, "Neoliberalism and privatisation in South Africa" GeoJournal 57 3-13

Navez-Bouchanine F, 1991, "L'espace limitrophe : entre le privé et le public, un no-man's land ? La pratique urbaine au Maroc" Espaces et Sociétés 62-63 135-159

Nemeth J, 2009, "Defining a Public: The Management of Privately Owned Public Space" Urban Studies 46 2463-2490

Ninot $\mathrm{O}$, Tallet $\mathrm{B}, 2014$, "Au delà des discours, quelles réalités pour les espaces ouverts en périphérie des métropoles des suds ? Approche comparative Le Cap/Mexico", in Métropoles aux Suds, le défi des périphéries ? Ed J-L Chaléard (Karthala, Paris) pp 411429

Oldfield S, Stokke K, 2006, "Building Unity in Diversity: Social Movement Activism in the Western Cape Anti-Eviction Campaign", in Voices of protest : social movements in postapartheid South Africa Eds R Ballard, A Habib, I Valodia (University of KwaZulu-Natal Press, Scottsville, South Africa) pp 111-134

Pithouse R, 2008, "A Politics of the Poor: Shack Dwellers' Struggles in Durban" Journal of Asian and African Studies 43 63-94

Plaut M, Holden P, 2012 Who rules South Africa? (Jonathan Ball, Cape Town)

Qian J, 2014, "Public Space in non-Western Contexts: Practices of Publicness and the Socio-spatial Entanglement" Geography Compass 8 834-847

Rancière J, 2000, "Dissenting words. A conversation with Jacques Rancière (with Davide Panagia)." Diacritics 30 113-126

Rancière J, 2003, "Politics and aesthetics: an interview" Angelaki: Journal of the Theoretical Humanities $\mathbf{8}$

Rancière J, 1999 Disagreement. Politics and Philosophy (University of Minnesota Press, Minneapolis)

Robinson J, 2003, "Postcolonialising Geography: Tactics and Pitfalls" Singapore Journal of Tropical Geography 24 273-289

Robinson J, 2006 Ordinary cities : between modernity and development (Routledge, London ; New York)

Robson M, 2005, "Introduction: Hearing voices" Paragraph 28 1-12

Ross K, 2002 May '68 and its afterlives (University of Chicago Press, Chicago)

Roy A, 2009, "The 21st-Century Metropolis: New Geographies of Theory" Regional Studies 43 819-830

Roy A, 2011, "Slumdog Cities: Rethinking Subaltern Urbanism" International Journal of Urban and Regional Research 35 223-238

Roy A, Ong A, 2011 Worlding cities : Asian experiments and the art of being global (WileyBlackwell, Chichester, West Sussex ; Malden, MA)

Sabatier B, 2006 La publicisation des espaces de consommation privés. Les complexes commerciaux récréatifs en France et au Mexique Thèse de géographie, Université de Toulouse II Le Mirail, Toulouse

Sakai A, 2011, "The hybridization of ideas on public parks: introduction of Western thought and practice into nineteenth-century Japan" Planning Perspectives 26 347-371 Samara T R, He S, Chen G, 2013 Locating right to the city in the Global South (Routledge, Abingdon, Oxon ; New York, NY)

Selmeczi A, 2012, "Abahlali's Vocal Politics of Proximity: Speaking, Suffering and

Political Subjectivization" Journal of Asian and African Studies 47 498-515 
Sheppard E, Leitner H, Maringanti A, 2013, "Urban Pulse-Provincializing Global Urbanism: A Manifesto" Urban Geography 34 893-900

Staeheli L A, Mitchell D, 2007 The People's Property? Power, Politics and the Public (Routledge, New York)

Swyngedouw E, 2014, "Where is the political? Insurgent mobilisations and the incipient "return of the political"" Space and Polity 18 122-136

Symphony Way Pavement Dwellers, 2011 No Land! No House! No Vote! Voices from Symphony Way (Pambazuka Press, Cape Town)

Szakolczai A, 1999 Reflexive Historical Sociology (Routledge, New York, NY)

Teppo A, Houssay-Holzschuch M, 2013, "Gugulethu ${ }^{\mathrm{TM}}$ : revolution for neoliberalism in a South African township" Canadian Journal of African Studies/La Revue canadienne des Études africaines 47 51-74

Thomassen B, 2014 Liminality and the Modern. Living through the In-Between (Ashgate, Burlington)

Toussaint J-Y, Zimmerman M, 2001 User, observer, programmer et fabriquer l'espace public (Presses polytechniques et universitaires romandes, Lausanne)

Watson S, 2006 City publics : the (dis)enchantments of urban encounters (Routledge, London ; New York)

Weintraub J A, Kumar K, 1997 Public and private in thought and practice : perspectives on a grand dichotomy (University of Chicago Press, Chicago)

Western J, 1996 Outcast Cape Town (University of California Press, Berkeley)

Worden N, Van Heyningen E, Bickford-Smith V, 1998 Cape Town : the making of a city : an illustrated social history (D. Philip / Verloren Publishers, Claremont, South Africa / Hilversum, Netherlands) 